\title{
CITRA PEREMPUAN DALAM PERIBAHASA MINANGKABAU
}

\section{Gusna Ronsi}

\begin{abstract}
This paper describes woman image in peribahasa Minangkabau. Data research were obtained from interview and literature observation. The peribahasa forms which contain woman image are gurindam, mamang, pepatah petitih, and seloka. The woman image in this forms are firm, kind, wise, deligent, and polite.
\end{abstract}

Key word: peribahasa, citra perempuan, Minangkabau

\section{Pengantar}

Kedudukan perempuan di Minangkabau dalam gambaran idealnya adalah kukuh, kuat dan angggun. Perempuan Minangkabau dilambangkan dengan predikat bundo kanduang. Dia adalah figur sentral dalam keluarga. Semua persoalan keluarga diserahkan kepadanya, dia adalah penentu kebijaksanaan dalam keluarga.

Figur bundo kanduang pada hakikatnya adalah nilai-nilai ideal perempuan Minangkabau itu sendiri. Terhadap bagaimana setiap perempuan Minangkabau dalam bersikap dan berperilaku. Berusaha menyesuaikan diri dan merupakan lambang dari kebudayaan Minangkabau itu sendiri, yang sifat dan ciri khasnya matrilineal.

Namun, kita perhatikan kondisi perempuan Minangkabau hari ini mulai berubah. Kekuatan perombak pertama adalah ekonomi dan pendidikan. Kehidupan masyarakat yang dulunya agraris, sekarang perlu adanya pelengkap. Hasil sawah dan harta kaum ternyata tidak mencukupi lagi dalam memelihara anggota kaum perempuan. Sehingga, sebahagian juga harus pergi meninggalkan kampung untuk mencari penghidupan di daerah lain. Hal ini didukung pula oleh tuntutan kehidupan yang semakin tinggi, baik itu faktor pendidikan maupun tuntutan kehidupan modern

WACANA ETNIK, Jurnal IImu Sasial dan Humaniora. ISSN 2098-8746. Volume 2, Nomor 1, April 2011. Halaman 39 - 58. 
lainnya. Anak-anak perempuan Minangkabau diperkenalkan dengan berbagai pendidikan formal yang makin berkembang.

Melalui pendidikan formal tersebut, sebagian orang Minangkabau makin tidak tergantung lagi kepada sawah. Hasil sawah hanya bisa bertahan untuk memenuhi kebutuhan pokok pangan semata. Masyarakat Minangkabau, tentu tidak ingin kehilangan kebudayaannya. Walaupun pada hakikatnya mengembalikan kepada bentuk awal tentulah sangat sulit. Pencitraan ideal perempuan Minangkabau perlu ditata kembali sesuai dengan semangat kembali ke adat asli. Salah satu sumber rujukan citra ideal perempuan Minang adalah peribahasa.

Peribahasa adalah ungkapan atau kalimat ringkas, padat yang berisi perbandingan, perumpamaan dan nasehat (KBBI, 1995: 265). Sehingga citra adalah gambaran, rupa yang dimiliki orang banyak mengenai pribadi, perusahaan, organisasi atau produk, kesan mental atau bayangan visual yang ditimbulkan oleh sebuah kata, frase atau kalimat.

Sebuah contoh peribahasa yang terdapat dalam cerita klasik Minangkabau (Kaba Sabai Nan Aluih).

samuik tapijak indak mati

'semut terinjak tidak mati'

alu tataruang patah tigo

'alu tersandung patah tiga'

(DT-KSN 2004)

Semut adalah jenis serangga yang hidup di tanah, terkadang semut juga merayap di jalur jalan manusia, besar kemungkinan ketika manusia berjalan dan menginjak semut maka semutnya akan mati terinjak. Akan tetapi, gambaran sosok perempuan Minangkabau yang dilukiskan dalam peribahasa di atas, begitu lembutnya perempuan Minangkabau melangkahkan kakinya semut yang kecil saja tidak mati.

Akan tetapi, alu yang tertarung akan patah tiga. Alu adalah sejenis kayu pilihan yang diambil dari dalam hutan, alu terbuat dari kayu yang lurus dan berat, dimana fungsinya untuk penumbuk padi secara tradisional oleh masyarakat Minangkabau. Alu, terbuat dari kayu yang berat saja, bisa patah tiga ketika tersandung oleh perempuan Minangkabau yang berjalan.

Dari uraian di atas terlihat dua karakter yang saling berseberangan, disatu sisi digambarkan karakter yang sangat lembut, semut terinjak tidak 
mati dan disisi lain karakter yang sangat keras, alu yang tersandung patah tiga. Peribahasa tersebut menggambarkan sosok perempuan yang lembut dalam keperibadian dan tegas soal hukum dan prinsip hidup.

Pada peribahasa tersebut digambarkan bahwa etnis Minangkabau menjadikan alam sebagai tempat belajar. Inspirasi berbahasa, lahir dari fenomena yang terjadi di alam. Hal ini sejalan dengan pendapat Duranti (1997:25) yang menyatakan bahwa bahasa mengkategorisasi realitas budaya, yaitu bagaimana melihat budaya suatu etnis dari cara berbahasanya.

Bertolak dari paparan di atas, kajian ini perlu dilakukan dan diharapkan dapat mengungkapkan berbagai aspek citra diri perempuan Minangkabau seutuhnya, sebagai cerminan realitas kehidupan masyarakat Minangkabau. Penulis berharap semoga dengan diangkatkan permasalahan ini, selesailah satu persatu dari tugas kita sebagai generasi pewaris tongkat estafet para pendahulu kita.

\section{Landasan Teori}

Hubungan bahasa dan kebudayaan sangat erat sekali, kebudayaan suatu etnis tidak akan bisa dipahami, sebelum mempelajari bahasanya dan begitu juga sebaliknya. Bahasa yang digunakan oleh suatu suku bangsa akan mencerminkan budaya pemilik bahasa tersebut.

Oktavianus (2006:118) mengatakan bahwa nilai budaya yang dimiliki suatu etnis, dapat ditelusuri melalui berbagai bentuk lingualnya. Dengan demikian, jelaslah bahwa bahasa dan budaya merupakan satu paket yang tidak bisa terpisahkan.

Bahasa merupakan bagian yang membentuk kebudayaan. Sibarani (2004:8) mengatakan ada tujuh unsur yang membentuk kebudayaan secara universal, (1) bahasa, (2) sistem pengetahuan, (3) organisasi sosial, (4) sistem peralatan hidup, (5) sistem mata pencaharian, (6) sistem religi, (7) kesenian. Bahasa ditempatkan pada posisi pertama karena manusia sebagai makhluk biologis harus berinteraksi dan berkomunikasi dalam kelompok sosial. Untuk berinteraksi dan berkomunikasi memerlukan bahasa.

Pada hakikatnya kebudayaan sangat kompleks sehingga para ahli selalu memberikan pengertian, pemahaman dan batasan yang bervariasi terhadap kebudayaan. Dalam pengertian yang sangat luas, Wilson (dalam Sibarani 2004:2) menyatakan bahwa kebudayaan pertama kali didefinisikan Taylor pada tahun pada tahun 1871, sebagai keseluruhan bidang yang meliputi pengetahuan, kepercayaan, seni, moral hukum, 
adat dan kemampuan-kemampuan lain yang diperoleh manusia sebagai anggota masyarakat. Batasan di atas, tampaknyabersifat penjumlahan dengan menyebutkan unsur-unsur kebudayaan itu sendiri, tetapi tidak menyebutkan sifat atau karakteristik umum semua unsur-unsur kebudayaan tersebut. Wilson (dalam Sibarani 2004:2) mengatakan bahwa kebudayaan adalah pengetahuan yang ditransmisi dan disebarkan secara sosial, baik bersifat eksistensial, normatif maupun simbolis yang tercermin dalam tindakan (act) dan benda-benda hasil karya manusia (artifact).

Perbedaan pandangan itu menjadi dasar berfikir dua paradigma besar tentang kebudayaan, yakni paradigma kognitif dan paradigma behavioris. Paradigma kognitif atau idesional melihat kebudayaan sama dengan pikiran (mind) manusia, sehingga sifatnya abstrak karena ada di kepala manusia baik berupa nilai-nilai, ide-ide pengetahuan maupun norma-norma. Menurut pandangan kognitif adanya tindakan berpola atau wujud fisik hanya sebagai akibat dari adanya kebudayaan manusia. Sehingga paradigma behavioris lebih mengartikan kebudayaan sebagai wujud tindakan (perilaku) berpola manusia yang dapat diamati secara kongkrit.

Kedua paradigma itu kemudian digabungkan, sehingga kebudayaan diartikan sebagai ide, tindakan dan hasil karya manusia. Pandangan itu diikuti oleh Koentjraningrat (dalam Sibarani 2004:3) yang mengatakan bahwa kebudayaan adalah sistem gagasan, tindakan dan hasil karya manusia dalam rangka kehidupan masyarakat yang dijadikan milik diri manusia dengan belajar.

Lebih jelasnya Murdock (dalam Sibarani 2004:4) mengatakan bahwa kebudayaan harus dipelajari. Artinya, kebudayaan harus ditransmisi dari orang yang lebih tua ke yang lebih muda, dari satu generasi kepada generasi yang lain. Duranti (1997:25) menyatakan bahwa bahasa mengkategorisasi realitas budaya, yaitu bagaimana melihat budaya suatu etnis dari cara berbahasanya. Bila diamati secara cermat, segala cipta karsa manusia tidaklah akan berkembang dengan baik apabila tidak diekspresikan dan disebarluaskan melalui bahasa.

Demikian pula, segala cipta dan karsa manusia tidak akan terbaca baik oleh manusia lainnya dari kelompok etnis yang sama atau oleh kelompok etnis lainnya dari kelompok yang berbeda. Bahasa dan budaya tampaknya erat kaitannya. Oleh sebab itu, sejalan dengan perkembangan ilmu, kajian tentang kebudayaan manusia tidak dapat dilepaskan dari kajian terhadap bahasanya. Demikian pula sebaliknya, kajian terhadap bahasa manusia 
tidak bisa dilepaskan dari kajian terhadap kebudayaan. Oktavianus (2006:53) mengatakan bahwa kajian bahasa dan budaya manusia ibarat dua sisi mata uang logam yang satu sama lainnya tidak bisa dipisahkan.

Dalam berbahasa, masyarakat dikategorikan menjadi dua: pertama masyarakat leksikal atau masyarakat yang cenderung bertutur secara langsung, kedua masyarakat metafora atau masyarakat yang cenderung bertutur tidak langsung. Salah satu masyarakat pengguna bahasa yang bertutur secara tidak langsung adalah masyarakat Minangkabau. Errington (dalam Oktavianus 2006:74) mengatakan bahwa salah satu ciri-ciri orang Minangkabau adalah mereka tidak berterus terang. Dengan kata lain, masyarakat Minangkabau cenderung memakai ujaran-ujaran yang mengandung makna implisit, atau dalam bahasa Minangkabau disebut dengan bahasa kias untuk mengungkapkan sesuatu. Tentu saja hal ini tidak terlepas dari latar belakang budaya Minangkabau itu sendiri.

Kridalaksana dalam Kamus Linguistik (2001:169) menyatakan bahwa peribahasa adalah kalimat atau penggalan kalimat yang telah membeku bentuk makna dan fungsinya dalam masyarakat, bersifat turun temurun dan dipergunakan untuk menghias karangan atau percakapan, penguat maksud karangan, pemberi nasihat, pengajaran atau pedoman hidup; mencakup bidal, pepatah, perumpamaan, ibarat dan pameo. Dari pengertian peribahasa menurut Kridalaksana di atas, jelas terlihat bahwa sebuah peribahasa baru dapat dimaknai dan dipahami secara utuh apabila berada dalam konteks atau latar budaya yang mengelilinginya, dalam hal ini budaya Minangkabau.

Navis (1984) mengatakan bahwa peribahasa di Minangkabau terdiri atas beberapa bentuk yakni, petatah-petitih, mamang, seloka dan gurindam. Mamang adalah peribahasa yang bentuk kalimatnya berupa dua bagian kalimat yang masing-masing terdiri dari dua atau empat buah kata. Kalimatnya mengandung arti sebagai pegangan hidup, suruhan, anjungan dan larangan. Gurindam adalah bentuk peribahasa yang tidak mempunyai sampiran, langsung berisikan saripati kata yang tersusun dari dua atau empat baris. Gurindam langsung masuk pada maksud dan isinya. Seloka adalah pantun empat baris yang terdiri dari beberapa untai. Tiap untai berhubungan erat dengan untaian berikutnya.

\section{Metode Penelitian}

Metode dan teknik yang penulis gunakan dalam penelitian ini adalah 
metode dan teknik penelitian bahasa yang dikemukakan oleh Sudaryanto (1993). Sudaryanto (1993: 9) membagi metode dan teknik penelitian bahasa ini menjadi 3, yaitu (1) metode dan teknik pengumpulan data atau penyediaan data, (2) metode dan teknik analisis data, (3) metode dan teknik penyajian hasil analisis data.

Dalam penelitian ini, penulis menggunakan dua sumber data yaitu data tulis dan data lisan. Metode yang digunakan adalah metode simak dan metode cakap. Sesuai dengan namanya, metode simak dilakukan dengan menyimak penggunaan peribahasa Minangkabau. Metode simak yang penulis gunakan ini mempunyai seperangkat teknik, yakni teknik dasar dan teknik lanjutan. Teknik dasarnya adalah teknik sadap. Peneliti dengan segenap kemampuan menyadap penggunaan peribahasa Minangkabau. Kemudian dilanjutkan dengan teknik lanjutan, Teknik Simak Libat Cakap (SLC). Kegiatan menyadap pertama-tama dilakukan dengan berpartisipasi sambil menyimak, penulis menyimak dan melibatkan diri dalam pembicaraan atau terlibat langsung dalam dialog baik aktif maupun reseptif (Sudaryanto:133-137). Teknik SLC adalah teknik dimana peneliti sendiri yang menjadi alatnya, yaitu penulis melibatkan diri secara langsung dalam membentuk dan memunculkan calon data. Metode dan teknik ini dilakukan untuk pengumpulan data lisan. Selanjutnya penulis menggunakan Teknik Simak Bebas Libat Cakap (SBLC), penulis tidak melibatkan diri dalam percakapan akan tetapi penulis hanya menyimak penggunaan peribahasa Minangkabau yang terdapat dalam berbagai sumber, dan dilanjutkan dengan teknik catat. Teknik SBLC ini digunakan untuk pengumpulan data tulis.

Sudaryanto (1993:137) mengatakan bahwa metode cakap adalah metode yang digunakan dalam pengumpulan data, dengan cara peneliti melakukan percakapan dan terjadi kontak dengan nara sumber. Pada metode cakap juga digunakan seperangkat teknik, yaitu teknik dasar dan teknik lanjutan. Teknik dasar dalam metode cakap adalah teknik pancing yakni, peneliti berusaha memancing orang yang dijadikan narasumber untuk berbicara, sehingga orang tersebut dapat memberikan data yang diinginkan peneliti. Kemudian dilanjutkan dengan teknik lanjut. Teknik lanjut terbagi atas dua, pertama Teknik Cakap Semuka (TCS), yakni peneliti mengarahkan pembicaraan sesuai dengan kepentingannya untuk memperoleh data selengkap-lengkapnya. Teknik lanjutan yang kedua adalah dengan teknik rekam dan teknik catat. Ketika teknik cakap semuka dilakukan, maka dilakukan pula perekaman dengan tape recorder dan 
pencatatan.

Informan dipilih berdasarkan kriteria tertentu dan dari latar belakang yang berbeda. Kriteria tersebut adalah (1) Berusia 30 tahun ke atas, (2) Penutur asli bahasa Minangkabau (3) Tempat tinggal di Minangkabau (4) memahami peribahasa dan ungkapan Minangkabau (5) memahami budaya Minangkabau (6) berdasarkan dari latar belakang yang berbeda-beda seperti tokoh adat, seniman, ulama (7) penyabar dan dinamis. Parameter lain yang digunakan untuk memilih informan adalah lokasi tempat tinggal, pekerjaan dan jenis kelamin. Ini sejalan dengan pendapat Samarin (dalam Oktavianus 2005:71) yang mengemukakan bahwa sejumlah orang yang dijadikan informan bahasa dipilih berdasarakan keriteria tertentu berdasarkan substansi, sifat dan tujuan penelitian.

Metode yang penulis gunakan dalam menganalisis data adalah metode padan. Alat penentu metode padan ini berada diluar, terlepas dan tidak menjadi bagian dari bahasa yang bersangkutan. Metode padan yang penulis gunakan adalah metode padan translasional dan metode padan pragmatik. Metode padan translasional adalah metode dengan alat penentunya berupa hasil translit (terjemah) ke dalam hasil bahasa yang diinginkan, dalam hal ini adalah bahasa Minangkabau diterjemahkan ke dalam bahasa Indonesia, sehingga apa yang dimaksud dan yang dibicarakan dapat dipahami. Metode padan pragmatik adalah metode yang menggunakan alat penentu berupa mitra wicara (konteks dan situasi) atas penggunaan peribahasa, dalam hal ini adalah budaya Minangkabau.

Dalam penyajian hasil analisis data, metode yang digunakan adalah metode informal. Metode informal adalah perumusan hasil analisis data dengan menggunakan kata-kata biasa. Metode informal juga merupakan interpretasi yang mendalam berupa pendeskripsian secara sistematis, faktual dan akurat mengenai data.

Metodeinformaljugamemuatpembahasanatassifat-sifatdanhubungan fenomena-fenomena yang diteliti, yaitu dengan mengimplikasikan teori yang digunakan, sebagaimana yang diungkapkan Sudaryanto (1993:145) bahwa penyajian data dengan menggunakan metode informal, hasil analisisnya akan terasa lebih rinci dan terurai. Deskripsi tentang fungsi dan makna dipaparkan secara deskriptif.

\section{Citra Perempuan dalam Peribahasa Minangkabau}

Perempuan mempunyai kedudukan yang penting dan istimewa 
dalam tataran adat Minangkabau. Keistimewaan yang diberikan kepada perempuan adalah suatu hal yang wajar, karena di Minangkabau menganut sistem matrilineal, suatu sistem yang memperhitungkan garis keturunan menurut garis ibu. Keberadaan suku, kaum, paruik tergantung pada eksistensi peran perempuannya dalam menjaga kaumnya.

Adat sebagai lembaga hukum dalam kebudayaan Minangkabau, mengatur perempuan menjadi figur ideal dalam menjalankan beberapa peran dan fungsinya. Begitu istimewanya keberadaan perempuan di Minangkabau, maka muncul berbagai ungkapan yang khusus untuk perempuan.

Berikut adalah peribahasa yang merangkum secara lengkap tentang peran sekaligus fungsi ideal perempuan Minangkabau. Hal tersebut dapat dilihat pada rangkaian peribahasa di bawah ini.

(1) limpapeh rumah nan gadang,

'kupu-kupu di rumah yang besar'

umbun puro pagangan kunci,

'bendahara pegangan kunci'

pusek jalo kumpulan tali,

'pusat jala ikatan tali'

sumarak di dalam kampuang

'semerbak didalam kampung'

hiasan dalam nagari,

'perhiasan di dalam negeri

ka pai tampek batanyo

'ketika akan pergi tempat bertanya'

ka pulang tampek babarito

'ketika sudah pulang tempat becerita'

kok hiduik tampek banasa

'tempat bernazar ketika hidup'

kok mati tampek baniaik

'ketika mati tempat berniat'

kaunduang-unduang kamadinah

'jadi kerudung ke Medinah'

kapayuang panji kasarugo

'jadi payung ke surga'

(DT-KTM 2010)

Peribahasa di atas disampaikan dalam bentuk petatah-petitih. 
Berdasarkan hasil wawancara dengan Musra Dahrizal Dt Katik Mangkuto, seorang Budayawan Minangkabau pada tanggal 27 Juli 2010 yang lalu, beliau menyampaikan bahwa secara falsafah, perempuan di Minangkabau dikenal dengan sebutan limpapeh rumah nan gadang 'kupu-kupu di rumah yang besar'. Dalam Kamus Umum Bahasa Minang (Abdul Kadir Usman, 2002:370) mengatakan bahwa limpapeh 'kupu-kupu' hiasan yang membuat semarak kaum keluarga dalam rumah. Sebutan khusus terhadap kemenakan perempuan dalam kaum pada masyarakat Minangkabau karena sejak kecil telah dididik sopan santun dan keterampilan mengerjakan urusan rumah tangga.

Menurut keterangan Musrah Dahrizal, dalam tradisi Minangkabau kehidupan kaum perempuan mengalami beberapa fase yang menyangkut status dan haknya dalam rumah tangga dan masyarakat. Sebelum sampai pada istilah limpapeh 'kupu-kupu', ada beberapa tahapan kata yang dipakai di Minangkabau untuk menggambarkan seorang perempuan.

Pertama, anak gadih 'anak gadis'. Istilah anak gadih ini digunakan mulai sejak lahir sampai batasan menikah, pada tahapan ini kehadirannya belum memberikan arti bagi lingkungannya. Perempuan Minangkabau menjalani persiapan sebagai calon pewaris tradisi yang berlanjut hingga ia remaja dan berakhir ketika menikah.

Kedua, padusi 'perempuan'. Secara falsafah, kata padusi berasal dari perlakuan orang tua kepada anak perempuan yang sudah menikah, disediakan sebuah kamar untuknya, tempat memadu kasih sayang dengan suaminya. Asal kata padusi berasal dari kata padu maka disebutlah dengan istilah padusi. Apabila perempuan Minang telah menikah, dalam adat Minangkabau sudah dianggap pantas untuk diperhitungkan keberadaannya. Ia telah mulai menjalankan beberapa fungsi dan peran serta mendapatkan hak-hak yang selayaknya dimiliki. Status sebagai istri merupakan pertanda bahwa seorang perempuan telah menjalankan kehidupan selengkapnya. Hal demikian juga sebagai lambang kepercayaan kepada seorang perempuan bahwa, ia telah dewasa dan mampu menjalani kehidupan masyarakat yang lebih luas dari rumah gadangnya, yakni menjadi menatu dalam keluarga besar suaminya.

Ketiga, parampuan 'perempuan'. Tempat berhimpunnya segala suka duka dan keluh kesah keluarga dihimpunkan pada ibu (mandeh). Oleh sebab itu, disebutlah dia perempuan. Di dalam rumah gadangnya, perempuan yang sudah menikah mendapatkan hak-hak yang menunjukkan bahwa 
ia telah berhak memakaikan adat dalam menyelesaikan segala persoalan keluarganya.

Keempat bundo kanduang. Dari kumpulan banyak perempuan ditunjuklah penghulu perempuan dan dialah yang dikenal dengan istilah bundo kanduang. Sebagai orang dewasa, perempuan berhak menjadi penentu dalam kebijaksanaan yang diambil di atas rumah gadang. Ketika ada lima atau enam orang mamak rumah 'laki-laki' yang sedang bermusyawarah di rumah gadang, kemudian datang bundo kanduang duduk di bagian belakang, maka sifatnya itulah yang dikenal dengan istilah limpapeh rumah nan gadang. Dalam bermasyarakat, ia mempunyai hak pula untuk bersuara memberikan pendapat selaku duta utama keluarga besarnya.

Kedudukan perempuan yang menjamin keberadaan suku atau kaum menyebabkan perempuan disimbolkan sebagai limpapeh rumah nan gadang. Karena keberadaan perempuan sebagai penjamin keberadaan suku (kaum), perempuan berkuasa atas harta benda kaumnya yang dinamakan sebagai umbun puro pagangan kunci 'bendahara pegangan kunci' bagi rumah gadang, yang akan memelihara harta benda itu dengan sebaik-baiknya demi jaminan hidup anak-anak serta kaumnya. Pusek jalo kumpulan tali, merupakan simbol yang menerangkan bagimana peran perempuan Minangkabau di dalam rumah tangganya. Sebagai pusat tempat berhimpunnya segala bentuk polemic yang dihadapi kaumnya, baik ditataran keluarga inti ataupun keluarga sepersukuan diserahkan kepadanya.

Ka pai tampek batanyo, 'jika pergi tempat bertanya' ka pulang tampek babarito 'jika pulang tempat berbagi cerita', maksudnya perempuan dijadikan mitra musyawarah. Mandeh kanduang adalah tempat berhimpunnya segala persoalan keluarga, sebelum sebuah perasalahan sampai ditataran musyawarah kaum, terlebih dahulu dimusyawarahkan dengan bundo kanduang. Citra ideal perempuan yang digambarkan dalam peribahasa Minagkabau di atas, menjelaskan bahwa perempuan di Minangkabau seharusnya diperlakukan sesuai dengan tuntutan adat tersebut.

Bentuk peribahasa Minangkabau yang mencitrakan perempuan. Terdapat dalam bentuk Pepatah-petitih, Mamang, Seloka, Gurindam. Pepatah-petitih merupakan ketentuan-ketentuan yang dinyatakan secara langsung dan tidak langsung, mengandung pengertian tersurat maupun tersirat atau kiasan (Hakimi, 1986:2). Mamang lazim juga disebut mamangan yang berarti pegangan (Navis, 1984:259). Kalimatnya mengandung arti sebagai pegangan hidup, sebagai suruhan, anjunran dan larangan. Bentuk 
kalimatnya berupa dua bagian kalimat yang yang masing-masing terdiri dari dua sampai empat buah kata. Navis (1984:237) mengatakan bahwa seloka adalah pantun empat baris yang terdiri dari beberapa untai. Tiap-tiap untai berhubungan dengan untai berikutnya. Pada penelitian ini ditemukan dua buah bentuk seloka. Navis (1984:238) mengatakan bahwa gurindam tidak mempunyai sampiran. Kalimatnya langsung masuk kepada maksud dan isinya.

Berikut merupakan penjabaran yang akan tentang citra perempuan Munangkabau dalam peribahasa.

\section{Tegas dan Lembut}

Tegas merupakan sikap yang senantiasa harus dimiliki oleh setiap manusia, tidak terkecuali perempuan. Ketegasan karakter perempuan Minangkabau, digambarkan dalam peribahasa. Ketegasan yang dimaksud adalah bagaimana ia menyikapi sebuah permasalahan yang timbul dalam kehidupan. Ketegasan perempuan Minangkabau dapat kita cermati pada peribahasa di bawahini.

(2) bajalan siganjua lalai

'berjalan siganjur lalai'

pado pai suruik nan labiah

'pada pergi surut yang lebih'

samuik tapijak indak mati

'semut terinjak tidak mati'

alu tataruang patah tigo

'alu tertarung patah tiga'

tibo di lasuang rampuak rampai

'tiba di lesuang rumpuk rampa'

(DL-KTM 2010)

Peribahasa pada data 2 ini berbentuk gurindam, tidak mempunyai sampiran dan langsung berisikan saripati kata serta terdiri atas lima baris. Peribahasa bajalan siganjua lalai 'berjalan siganjur lalai' pado pai suruik nan labiah 'pada pergi surut yang lebih' samuik tapijak indak mati 'Semut terinjak tidak mati' alu tataruang patah tigo' alu tersandung patah tiga' tibo di lasuang rampuak rampai 'sampai di lesung rempuk rampa' menggambarkan sosok ideal perempuan Minangkabau. Rangkaian peribahasa tersebut menyatakan bahwa perempuan Minangkabau memiliki kepribadian yang 
lembut dan sangat kuat secara prinsip, tegas dan bijaksana. Melangkah dengan langkah yang tenang, tidak tergesa-gesa dan bukan berarti lambat. Peribahasa ini menjelaskan ketangkasan dan ketinggian budi seorang perempuan Minangkabau, tidak menindas yang kecil dan juga tidak lemah ketika dihadapkan dengan permasalahan yang besar.

Dari data 2 di atas, tercermin bahwa perempuan dalam budaya Minangkabau memiliki sifat yang tegas dan lembut. Kelembutannya dapat dilihat pada peribahasa samuik tapijak indak mati, 'semut terinjak tidak mati' dan ketegasannya dilihat dari alu tataruang patah tigo, 'alu tertarung patah tiga'. Pada dasarnya untaian peribahasa tersebut lebih mengacu pada sifat dan kepribadian perempuan Minang yang dituntut dalam adat Minangkabau untuk memiliki sifat lembut dalam kepribadian dan tegas soal prinsip.

\section{Sopan Santun}

Sikap sopan santun merupakan karakter yang disukai dalam masyarakat. Dalam percakapan sehari-hari ada sepenggal kalimat yang sering kita dengar, anda sopan kamipun segan. Artinya, sifat sopan santun akan menjadikan seseorang dihargai dan disegani oleh orang lain. Sebagai panutan dan representasi dari sebuah kaum, sudah sejatinya perempuan Minangkabau mencerminkan sifat sopan dan santun tersebut. Peribahasa Minangkabau menggambarkan sifat sopan santun ini seperti terlihat di bawah ini.

(3) panggalak jago lalok

'tersenyum ketika bangun tidur'

panyanang diurang tibo

senang ketika tamu datang'

(DT-KTM)

Data 3 berbentuk mamang, yakni peribahasa yang bentuk kalimatnya berupa dua bagian kalimat yang masing-masing terdiri dari dua kata. Kalimatnya mengandung arti sebagai pegangan hidup, suruhan, anjuran dan larangan. Suasana ketika bangun tidur adalah saat-saat dimana seseorang masih belum stabil kondisinya, belum bisa mencerna suasana dengan baik. Biasanya, orang yang baru bangun tidur akan memasang wajah cemberut dan tidak banyak bicara. Maksud yang ingin disampaikan 
dalam peribahasa panggalakjago lalok 'tersenyum disaat bangun tidur' adalah perempuan Minang walaupun, dalam kondisi sulit dan pada suasana yang susah masih bisa tersenyum. Peribahasa selanjutnya menegaskan panyanang di urang tibo 'senang ketika tamu datang', maksudnya adalah perempuan Minang akan selalu memasang wajah yang ceria ketika ada orang yang berkunjung ke rumahnya. Sepahit dan sesempit apapun kondisi hidup yang sedang dialalaminya. Sebisa mungkin ia akan berusaha menutupi apapun masalah yang sedang dihadapi keluarganya. Budaya sopan santun yang dimiliki perempuan Minangkabau, terlihat jelas dari cara berbahasa mereka. Sikap sopan santun ini juga bisa kita lihat dalam peribahasa lain seperti di bawah ini.

(4) muluik manih,

'bermulut manis'

kucindan murah

'suka bercanda'

(DT-Hakimi 1978)

Bentuk peribahas data 4 adalah mamang. Peribahasa ini menggambarkan kecerdasan perempuan Minang dalam memilih dan memilah penggunaan katakata, agar mitra tutur tidak tersinggung karenanya. Muluik manih 'bermulut manis' maksudnya bertutur kata dengan kata-kata yang manis. Seseorang yang mempunyai tutur sapa yang manis dan sopan sangat disukai orang. Baik itu berbicara kepada orang yang lebih tua, sesama besar maupun kepada yang lebih kecil. Dalam Kamus Bahasa Minang (Erwina Burhanudin, dkk, 2009) kuncindan berarti canda. Kucindan murah 'mudah bercanda', maksudnya adalah perempuan Minangkabau dalam tuntutan adat adalah pandai bercanda, memiliki rasa humor dan tidak kaku. Ketika berbicara, canda juga diperlukan untuk agar lawan bicara senang dengan kita, bisa menghidupkan suasana pertuturan. Perempuan yang suka bercanda sewajarnya merupakan sosok idola orang tua-tua untuk generasinya.

Kemampuan berkata-kata adalah bagian kesopan santunan dalam budaya Masyarakat Minangkabau. Perempuan yang memiliki sifat muluik manih, kucindan murah akan lebih disenangi banyak orang. 


\section{Teguh Pendirian}

Teguh pendirian merupakan perilaku konsisten yang tidak mudah terpengaruh oleh lingkungan maupun pengaruh yang datang dari luar. Sikap teguh pendirian ini sangat bergantung kepada setiap individu yang memaknai berbagai pengaruh yang datang. Perempuan di Minangkabau harus peka terhadap berbagai pengaruh yang datang, ia tidak boleh terpengaruh dengan berbagai fenomena yang ada, apalagi pengaruh itu merusak atau bahkan menghilangkan nilai-nilai yang telah tertanam bagi perempuan Minangkabau.

Peribahasa ini menggambarkan keteguhan pendirian yang harus dimiliki oleh perempuan Minangkabau.

(5)diam di banda tak maniru

'tinggal di kali tidak meniru'

diam di lauik masin tidak

'tinggal di laut tidak asin'

(DT-OK 2010)

Data 5 berbentuk gurindam yaitu, peribahasa yang tidak mempunyai sampiran lansung berisikan saripati kata yang tersusun dalam dua atau empat baris. Gurindam lansung masuk pada maksud dan isi. Peribahasa di atas, merupakan implikasi dari falsafah orang Minang Alam Takambang Jadi Guru. Alam bagi orang Minangkabau tidak hanya sebagai tempat hidup, akan tetapi alam juga sebagai tempat untuk belajar. Peribahasa diam di banda tak maniru 'tinggal di kali tidak meniru' diam di lauik masin tidak 'tinggal di laut tidak asin'.

Ikan adalah makhluk yang hidup di air. Ikan yang hidup dalam air laut yang asin, tidak mempengaruhi dagingnya juga ikutan asin. Danging ikan tetap terasa tawar, artinya adalah walaupun lingkungan disekelilingnya tidak sesuai dengan yang diharapkan, tidak membuatnya melebur dengan suasana yang ada.

Data 5 di atas, merupakan gambaran perempuan Minangkabau dalam mempertahankan prinsip hidupnya, dalam menghadapi tantangan zaman. Maksudnya adalah dalam kondisi bagaimanapun, perempuan Minangkabau dalam tuntutan peribahasa tidak mudah terbawa arus zaman, mereka berbaur tapi tidak melebur dengan suasana yang ada. 


\section{Arif dan Bijaksana}

Bijaksana merupakan suatu sikap yang arif. Sikap arif membuat seseorang dihargai dan disegani, baik di lingkungan kaum maupun masyarakatt.Sikapbijaksanalebihdekatpadakeadilan dalammenyelesaikan sebuah permasalahan, tidak ada satu pihakpun yang merasa dirugikan. Sikap bijaksana ini di gambarkan dalam peribahasa Minangkabau berikut.

(6) pandai mambuhua tak mangasan

'pandai membual tidak tampak'

pandai mauleh tak babuku

'pandai menyambung tidak berbuku'

(DT-Hakimi 1978)

Data 6 juga berbentuk gurindam. Peribahasa di atas, menggambarkan sikap bijaksana dengan pandai mambuhua tak mangasan, 'pandai membual tidak tampak' maksudnya adalah walupun ada keganjilan maupun sedikit rasa tidak senang terhadap orang lain, tapi tetap bisa disembunyikan seolah-olah tidak terjadi apa-apa. Biasanya buhua ini digunakan untuk tali yang sudah putus kemudian disambung kembali, akan tetapi hasil buhua tersebut tidak berbekas sehingga terkesan tidak ada buhua 'bualan' dari sambungan tali yang putus. Jadi pandai mambuhua tak mangasan maksudnya adalah kebijaksanaan yang diambil oleh seorang perempuan Minangkabau, dalam memutuskan sebuah permasalahan sehingga tidak ada pihak yang merasa dirugikan. Hal ini sejalan dengan peribahasa berikutnya, pandai mauleh tak babuku, 'pandai menyambung tidak berbuku'. Buku adalah batasan antara ruas dengan ruas. Maksudnya ketika menyambungkan tali, hasil sambungan ini tidak meninggalkan bekas.

Begitu bijaksananya perempuan Minangkabau, ketika mendamaikan perselisihan antaranggota keluarga maupun kaum, tidak ada pihak yang merasa dirugikan. Hal ini tidak menimbulkan rasa kecemburuan dari kedua belah pihak yang berselisih.

\section{Rajin dan Ulet}

Rajin merupakan sifat positif yang harus dimiliki oleh seseorang. Tidak terkecuali perempuan Minangkabau. Untuk mendapatkan apa yang kita citacitakan, terlebih dahulu kita harus menanamkan prinsip rajin di dalam diri kita. Etos kerja yang tinggi dalam berusaha akan menumbuhkan 
sikap yang baik pada setiap individu. Peribahasa berikut menggambarkan etos kerja dan keuletan perempuan Minangkabau dalam menjalani kehidupannya. Hal tersebut dapat dilihat dalam peribahasa di bawah ini.

(7) hari sahari di parampek

'satu hari di bagi empat' malam samalam di patigo 'satu malam dibagi tiga' (DT-Hakimi 1978)

Data 7 berbentuk mamang, hari sahari diparampek 'satu hari dibagi empat'. Maksudnya adalah memanfaatkan waktu yang tersedia dengan sebaikbaiknya, dengan cara menuntaskan semua pekerjaan sesuai dengan target waktu yang desediakan. Selanjutnya malam samalam dipatigo 'satu malam dibagi tiga' maksudnya adalah, malam tidak semata digunakan untuk waktu istirahat atau tidur saja, akan tetapi sebagian waktu dimalam hari juga dapat dimanfaatkan untuk pekerjaan-pekerjaan yang bermanfaat.

Peribahasa di atas menjelaskan bahwa dalam Budaya Minangkabau, penggunaan waktu sangat diperhatikan. Tidak hal yang sia-sia, setiap saat dan keadaan pasti ada hal yang bisa diperbuat. Pemanfaatan setiap kondisi dan keadaan dapat kita lihat pada ungkapan adat yang mengatakan bahwa, nan buto paambiuh lasuang 'orang buta peniup lesung', nan pakak palapeh badiah 'orang tuli pelepas bedil', nan lumpuah paunyi rumah 'orang lumpuh penghuni rumah'.

Ungkapan di atas, menjelaskan bahwa dalam etnis Minangkabau segala kondisi dan keadaan pasti ada manfaatnya. Pendapat ini, sejalan dengan pernyataan Duranti (1997:25) yang menyatakan bahwa bahasa mengkategorisasi realitas budaya, yaitu bagaimana melihat budaya suatu etnis dari cara berbahasanya. Dari peribahasa di atas, dapat dilihat kategori masyarakat Minangkabau, digambarkan etnis yang rajin dan ulet.

\section{Waspada}

Kewaspadaan identik dengan kehati-hatian. Orang yang hati-hati dalam bertindak biasanya memiliki kewaspadaan dan demikian pula sebaliknya. Seperti halnya kehati-hatian, kewaspadaan juga membentuk pencitraan diri seseorang. Kewaspadaan digambarkan melalui ungkapan berikut: 
(8) ingek sabalun kanai, kulimek sabalun abih, 'ingat sebelum kena, hemat sebelum habis' (DT-OK 2010)

Data 8 juga berbentuk mamang. Peribahasa ingek sabalun kanai 'ingat sebelum kena' merupakan nasehat yang berisi peringatan agar waspada dalam berbagai hal. Melalui teknik parafrase yang dikemukakan oleh Wierzbicka (dalam oktavianus 2006:59) kanai 'kena' secara leksikon dapat diartikan tertimpa atau menderita sesuatu kerugian dan kesusahan akibat suatu perbuatan. Jadi, ungkapan ingek sabalun kanai 'ingat sebelum kena' dapat diberlakukan dalam berbagai aktivitas sehari-hari. Ungkapan ini sejalan dengan kulimek sabalun abih 'berhemat sebelum habis'. Peribahasa di atas memberikan isyarat agar orang tidak boros sehingga dia tidak mengalami kesusahan pada hari-hari berikutnya. Peribahasa di bawah ini menjelaskan bagaimana perempuan Minang di rumah gadangnya.

(9) umbun puro pagangan kunci.

'bendahara pegangan kunci'

(DL-KTM 2010)

Sama dengan beberapa data di atas, data 9 juga berbentuk mamang. Sebagai umbun puro pagangan kunci 'bendahara pegangan kunci' di rumah gadang, perempuan Minangkabau dituntut untuk bersikap hemat dan teliti dalam mengelola harta kaum. Seluruh bentuk pengelolaan harta kaum diserahkan kepada perempuan sepenuhnya. Peribahasa lain yang menggambarkan konsep kewaspadaan, terlihat seperti di bawah ini.

(10) kana rantiang nan ka mancucuak

'ingat ranting yang akan menusuk'

duri nan ka mangaik

'duri yang akan menyangkut'

(DT-OK 2010)

Data 10 berbentuk gurindam. Dari peribahasa di atas, terlihat adanya kewaspadaan terhadap semua kemungkinan yang terjadi. Kana rantiang nan ka mancucuak 'ingat ranting yang akan menusuk', ranting adalah bagian 
dari pohon yang terdapat di dahan pohon, kalau tidak hati-hati berjalan di bawah pohon maka mata akan ditusuk ranting. Begitu juga dengan peribahasa berikutnya, duri nan ka mangaik 'duri yang akan menyangkut'. Ketika berjalan, kalau tidak hati-hati maka akan tersangkut duri. Artinya adalah kapan dan dalam kondisi bagaimanapun kita harus selalu waspada terhadap apapun yang akan terjadi. Jangan sampai karena tidak waspada kita celaka.

Begitu cermatnya peribahasa Minangkabau menggambarkan sosok perempuan yang dituntut dalam budaya Minang, bersikap waspada dan hati-hati terhadap setiap kemungkinan yang akan mencelakai. Sebelum semuanya terjadi, sudah di waspadai terlebih dahulu.

\section{Penutup}

Dalam budaya Minangkabau perempuan digambarkan dengan tuturan tidak langsung. Gambaran tentang mereka diungkapkan dengan bentuk bahasa khusus yaitu kias. Bentuk bahasa kias yang mereka gunakan adalah peribahasa.Masyarakat Minangkabau termasuk suatu etnis yang tidak terus terang dalam berbahasa. Mereka cenderung bertutur tidak langsung dan peribahasa merupakan salah satu model berbahasa orang Minangkabau.

Dari hasil penelitian ini disimpulkan bahwa peribahasa Minangkabau yang mencitrakan perempuan terdiri atas beberapa bentuk yakni, mamang, gurindam, pepatah-petitih, dan seloka. Pada penelitian ini ditemukan citra perempuan dalam peribahasa sebagai orang tegas dan lembut, sopan santun, teguh pendirian, arif dan bijaksana, rajin dan ulet serta waspada. Perlakuan yang dituntut peribahasa terhadap perempuan Minangkabau adalah sebagai orang yang dihormati dan dihargai, orang yang dijaga dan dilindungi serta orang yang diteladani.

Secara budaya, perempuan di Minangkabau merupakan sosok sentral dalam kaum. Ini terbukti dengan adanya peribahasa khusus tentang perempuan. Bagaimana perempuan seharusnya menempatkan diri dan berperilaku ditataran kaum maupun masyarakat. Ditataran kaum, perempuan merupakan teladan bagi kaumnya, baik buruknya sebuah kaum dilihat dari perilaku perempuannya dalam masayarakat. Dari analisis terhadap peribahasa pada bab sebelumnya, terlihat juga bahwa emansipasi ada dalam kebudayaan Minangkabau. Perempuan melibatkan diri dalam urusan kemasyarakatan, sama halnya dengan laki-laki. Merekamempunyai 
wewenang pada tataran kaum di rumah gadang juga sebagai penentu keputusan kaumnya.

\section{Daftar Pustaka}

Burhanudin, Erwina,dkk. 2099. Kamus Bahasa Minangkabau-Indonesia. Padang : Balai Bahasa.

Duranti, Alessandro. 1997. Rangkuman terjemahan Linguistik Antropologi. Combridge: University Press.

Irfah. 1993. “Wanita dalam Petatah-Petitih Minangkabau” (skripsi). Padang: Universitas Andalas.

Kridalasana, Harimurti. 2001. Kamus Linguistik. Jakarta: PT Gramedia pustaka Utama.

Naim, Mochtar. 2006. Perempuan Minangkabau di Persimpangan Jalan. Jakarta: Hasanah.

Navis, A. A. 1984. Alam Terkembang Jadi Guru. Jakarta: Grafiti Pers

Nurhayati. 2005. “Analisis Wacana Pertengkaran di kenagarian Aie Dingin Kecamata Lembah Gumanti Kabupaten Solok: Studi Kasus" (skripsi). Padang: Universitas Andalas.

Oktavianus. 2006. Analisis Wacana Lintas Bahasa. Padang: Andalas University Press.

Oktavianus. 2005. "Kias dalam Bahasa Minangkabau" (disertasi). Program pasca sarjana Universitas Udayana.

Parera, J. D. 2004. Teori Semantik. Jakarta: Erlangga

Revita, Ike. 2007. "Permintaan dan Penolakan dalam Bahasa Minangkabau" (disertasi). Program pasca sarjana Universitas Gajah Mada.

Rizal. Y. 2003. 3000 Peribahasa Indonesia. Bandung: Pustaka Setia

Rizal. Y. 1996. Hubungan antara pantun dengan peribahasa MinangkabauIndonesia. Bandung: Pustaka Setia.

Saleh, Abd, dkk. 1999. Ungkapan Minangkabau. Padang: laporan penelitian oleh lembaga kerapatan Adat Alam Minangkabau.

Sibarani, Robert. 2004. Antropolinguistik. Medan: Poda.

Sudaryanto. 1993. Metode dan Aneka Teknik Analisis Bahasa. Yogyakarta: Gadjah Mada University Press

Sumarsono. 2002. Sosiolinguistik. Yogyakarta: SABDA

Usman, Abdul Kadir. 2002. Kamus Umum Bahasa Minangkabau Indonesia. Padang: Anggrek Media

Yuskanedi. 1996. "Moralitas Perempuan Minangkabau dalan Novel Wrisan Karya Khairul Harun" (skripsi). Padang: Universitas Andalas.

\section{DAFTAR SINGKATAN}

DL-KTM : Data Lisan Wawancara dengan Katik Mangkuto Juli 2010DTIDRUS : : Data Tulis dalam Buku Idrus Hakimi 1978

DT-RIZAL : Data Tulis dalam Buku Yose Rizal 1996

DT-OK : : Data Tulis Oktavianus 2010

DT-KSN : Data Tulis Kaba Sabai Nan Aluih 2004 
